\title{
Obtaining L - Glutamate Oxidase Enzyme from Streptomyces and Estimation Its Toxicity on Blood Components
}

\author{
Dina H. Abdul Hameed*, Entesar H. Ali \\ Biotechnology Division, Department of Applied Science, University of Technology - Iraq
}

\section{Article information}

Article history:

Received: July, 23, 2021

Accepted: October, 09, 2021

Available online: December, 04, 2021

Keywords:

L-glutamate oxidase,

Streptomyces,

Optimum $\mathrm{pH}$

*Corresponding Author:

Dina H. Abdul Hameed

as.18.15@grad.uotechnology.edu.iq

\begin{abstract}
Streptomyces was isolated from the soil and then tested to diagnose morphologically and microscopically. Also, cultivated in the production medium of the L - glutamate oxidase enzyme, for which the wheat bran culture media was used, and then the extracellular L - glutamate oxidase enzyme was extracted using a cooling centrifuge at $8000 \mathrm{rpm}$ for 20 minutes. The optimal temperature and $\mathrm{pH}$ for the production of the enzyme's conditions were studied. Research results revealed that the optimum temperature for enzyme production was $30^{\circ} \mathrm{C}$, and the best $\mathrm{pH}$ for the enzyme's production was 7.0 later on, the enzyme was purified using common purification techniques represented by precipitation with ammonium sulfate as a preliminary purification step, followed by dialysis to remove salts, ion-exchange chromatography and gel filtration chromatography were used to finish purification process. The effect of the enzyme toxicity on the human blood components was evaluated. The enzyme had no harmful effect on the blood cells, with Red Blood Cells reaching 4 x 10 ${ }^{12}$, White Blood Cells $7.5 \times 10^{9}$ and Platelets $293 \times 10^{9}$.
\end{abstract}

DOI: 10.53293/jasn.2021.4042.1069, Department of Applied Sciences, University of Technology

This is an open access article under the CC BY 4.0 License.

\section{Introduction}

Enzymes are protein molecules that function as biological catalysts, speeding up chemical processes without being consumed, and they mediate nearly all reactions in the body. Enzymes are made from live cells and have the advantage of being able to function since biological catalysts stay active even after being removed or separated from the cells. They also exhibit a high degree of selectivity in the reactions they catalyze as well as in their interactions with the substrate. Enzymes are always catalysts, and a tiny quantity of enzymes in comparison to the substrate is enough to accelerate the process. Where the mechanism of action of enzymes is based on a chemical reaction in which the enzyme binds to the substrate and creates an enzyme-substrate complex. At the active site of an enzyme, a relatively tiny location is known as the active site [1]. The enzyme is affected by temperature and $\mathrm{pH}$. The temperature has a large influence on enzyme reaction rates, as it impacts them through two opposing processes. 1) Activation: when the reaction speed increases as the temperature rises. 2) Denaturation: Denaturation occurs at high temperatures ranging from 50 to 60 degrees Celsius, except for thermophilic enzymes, wherein denaturation occurs at temperatures over 60 degrees Celsius. The optimum temperature for the enzyme, which can vary from $25-40{ }^{\circ} \mathrm{C}$, is known as the best temperature at which the enzyme is most active and converts the largest amount of the substrate into products [2]. While $\mathrm{pH}$ alters the enzymatic activity due to its effect on the side chains of proteins. Each enzyme has an ideal $\mathrm{pH}$ number and one for its effectiveness, but some enzymes have more than that, and this number is usually in a very narrow range, but some enzymes show a wide range for it [3]. 
Streptomyces is the most abundant genus of actinomycetes accounting for half of all soil actinomycetes. Streptomyces spp. also produces a wide variety of novel antibiotics than any other actinomycetes genera. Different species of Streptomyces produce around 6000 different antibiotics, many of which are commercially available as anti-infective (antibiotics, antifungal, and antiparasitic), anticancer, or immunosuppressant agents [4]. They may be found in nearly all habitats, and they are gram-positive, aerobic, non-motile, and filamentous. Streptomyces have genomes with high $(\mathrm{G}+\mathrm{C})$ content of $69-78 \%$ and they are spore-forming microbes [5]. These bacteria produce aerial hyphae that get divided, resulting in spores that can withstand harsh circumstances and spread quickly to new habitats or sources of food. Streptomyces produce secondary metabolites during the growth phase, which are chemicals that are not essential for growth or reproduction but might provide the organism with competitive benefits [6]. The colonies are slow-growing and relatively soft which developed later on into a granular or velvety appearance. It often has a soil-like odor due to its production of a secondary metabolic compound known as Geosmin [7].

Streptomyces strains such as S.somaliensis and S.sudanensis cause infectious human diseases such as mycetoma. It is an inflammatory disease that causes the skin, subcutaneous tissue, and muscles of the body to gradually become inflamed. Furthermore, some species do not exist in the soil but coexist with plant roots and can cause disease. For example, potato scab disease is caused by the bacteria Streptomyces scabis [8]. L-glutamate oxidase (LGOX) [EC 1.4.3.11] from Streptomyces It has a molecular weight of $150 \mathrm{KDa}$ and has a hexamer structure consisting of $\alpha_{2} \beta_{2} \gamma$. L - glutamate oxidase enzyme induces the oxidative deamination of an L-glutamate to an $\alpha$ ketoglutarate, ammonia, and hydrogen peroxide. This enzyme is a valuable analytical tool for measuring Lglutamate levels in food and during the fermentation process. It also gained a lot of interest because of the possibility of using it to diagnose liver function. In the clinical laboratory, it might be used to evaluate serum Glutamate Oxaloacetate Transaminase (GOT) and Glutamate Pyruvate Transaminase (GPT) levels. The enzyme L-glutamate oxidase extracted from the genus Streptomyces is an exoenzyme that is stable in temperature and acidity. It is also classified as one of the flavoproteins because it includes a flavin group that is not covalently bound as a cofactor [9].

This work aimed to expand the studies of the enzyme and giving the facts that the researches on L - glutamate oxidase enzyme production and application in Iraq have not been conducted so far, this may be the first study on it. This study was carried out to identify the optimal conditions for enzyme production as well as to determine whether the locally purified enzyme from Streptomyces has any toxic or harmful effects when mixed with human blood. Additionally, this study focused on comparing its toxicity to that of toxic hydrogen peroxide on human blood components.

\section{Materials and Methods}

\subsection{Sample Identification}

Streptomyces bacteria were isolated from the soil and cultivated on nutrient agar medium and starch casein agar for 48 hours at $30^{\circ} \mathrm{C}$, after that they were identified by morphological and microscopic characteristics and biochemical tests [10].

\subsection{Enzyme Production}

To produce the L-glutamate oxidase enzyme, bacteria were implanted in the enzyme production media for 60 hours in a shaking incubator, and because the enzyme is extracellular, thus it was centrifuged for 20 minutes at $8000 \mathrm{rpm}$ in a cooling centrifuge. The filtrate that containing the enzyme was collected and the precipitate was discarded, after that the enzyme was purified to get it singly and purely to be used in various applications [11].

\subsection{Determination of Optimum pH for L- Glutamate Oxidase Production}

To determine the optimum $\mathrm{pH}$ for enzyme production, the $\mathrm{pH}$ of the prepared culture medium was changed to (3, $5,7,8,9)$ which contains $1 \mathrm{ml}$ of Streptomyces culture and the age of culture was 48 hours in the shaking incubator at 60 hours. After that the activity of the enzyme produced by bacteria was measured after extraction to determine the optimum $\mathrm{pH}$ for production [12]. 


\subsection{Determination of Optimum Temperature for L- Glutamate Oxidase Production}

To determine the optimum temperature for enzyme production, the prepared culture medium which contains $1 \mathrm{ml}$ of culture the age of culture was 48 hours were incubated at different temperatures $(20,25,30,37,40)^{\circ} \mathrm{C}$ in the shaking incubator for 60 hours, then the activity of the enzyme produced by bacteria was measured after extraction to find the optimum temperature for production[12].

\subsection{Evaluation of the Toxic Effect of Enzyme on Human Blood Components}

This experiment aimed to distinguish whether the enzyme has any toxic effect on human blood cells by automated analysis utilizing a hematological apparatus (Mindray) which is a novel hematological analyzer specifically designed for complete blood count [13]. Random blood samples were obtained at a rate of $3 \mathrm{ml}$ from healthy persons in specialist laboratories, then $1 \mathrm{ml}$ was placed in tubes containing EDTA, where these samples were treated once with the enzyme L-glutamate oxidase and once with hydrogen peroxide, where 10 microliters of each substance were added to the blood tubes, then the tubes were incubated for an hour, after which the result was read and the results were compared with the control [14]

\begin{tabular}{|c|c|c|c|c|}
\hline $\begin{array}{c}\text { Number of } \\
\text { samples }\end{array}$ & Ages & $\begin{array}{c}\text { Enzyme } \\
\text { (Microliter) }\end{array}$ & $\begin{array}{c}\text { Hydrogen } \\
\text { peroxide } \\
\text { (Microliter) }\end{array}$ & $\begin{array}{c}\text { Control } \\
\text { (Blood only) }\end{array}$ \\
\hline $\begin{array}{c}5 \text { Males } \\
5 \text { Females }\end{array}$ & $25-30$ & 10 & 10 & $1 \mathrm{ml}$ \\
\hline
\end{tabular}

\section{Results and Discussion}

\subsection{Identification of Bacteria}

The process of identifying bacteria began with cultivating the samples and incubating them for 48 hours at $30^{\circ} \mathrm{C}$, followed by a biochemical test to confirm that the isolate belonged to Streptomyces. The results obtained are in agreement with the description in (Rong and Ming 1995) [15].

Table 1. Characteristics of Streptomyces.

\begin{tabular}{|c|c|}
\hline Characteristics of Streptomyces & Results \\
\hline Cultural Characteristics & $\begin{array}{c}\text { On starch casein agar as its diagnostic medium } \\
\text { Shape: filamentous and round } \\
\text { Chromogenesis: White and cream } \\
\text { Surface: powdery } \\
\text { Consistency: dry }\end{array}$ \\
\hline Biochemical Tests & $\begin{array}{l}\text { Oxidase: positive } \\
\text { Catalase: positive }\end{array}$ \\
Gram Stain & $\begin{array}{l}\text { Positive } \\
\text { Purple filamentous }\end{array}$ \\
\hline
\end{tabular}




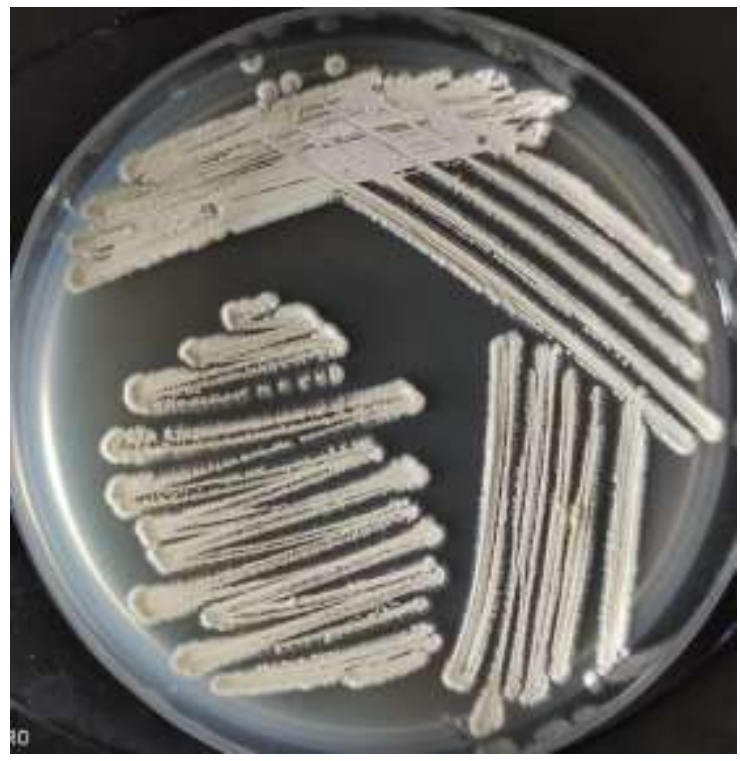

Figure 1. Streptomyces bacteria on starch casein agar.

\subsection{Optimum Temperature for Enzyme Production}

The results revealed that the optimum temperature for the production of the enzyme is $30^{\circ} \mathrm{C}$, as shown in Figure (2), with the highest specific activity reaching to 4.5 units per milligram protein at the temperature $30^{\circ} \mathrm{C}$, and the lowest specific activity of the enzyme was 2.7 units per $\mathrm{mg} /$ protein at the temperature $20^{\circ} \mathrm{C}$, based on these findings the temperature of $30^{\circ} \mathrm{C}$ was chosen as the ideal temperature for the enzyme. This is consistent with [16], which showed that the best temperature for the production of the L- glutamate oxidase enzyme from bacteria is $30{ }^{\circ} \mathrm{C}$.

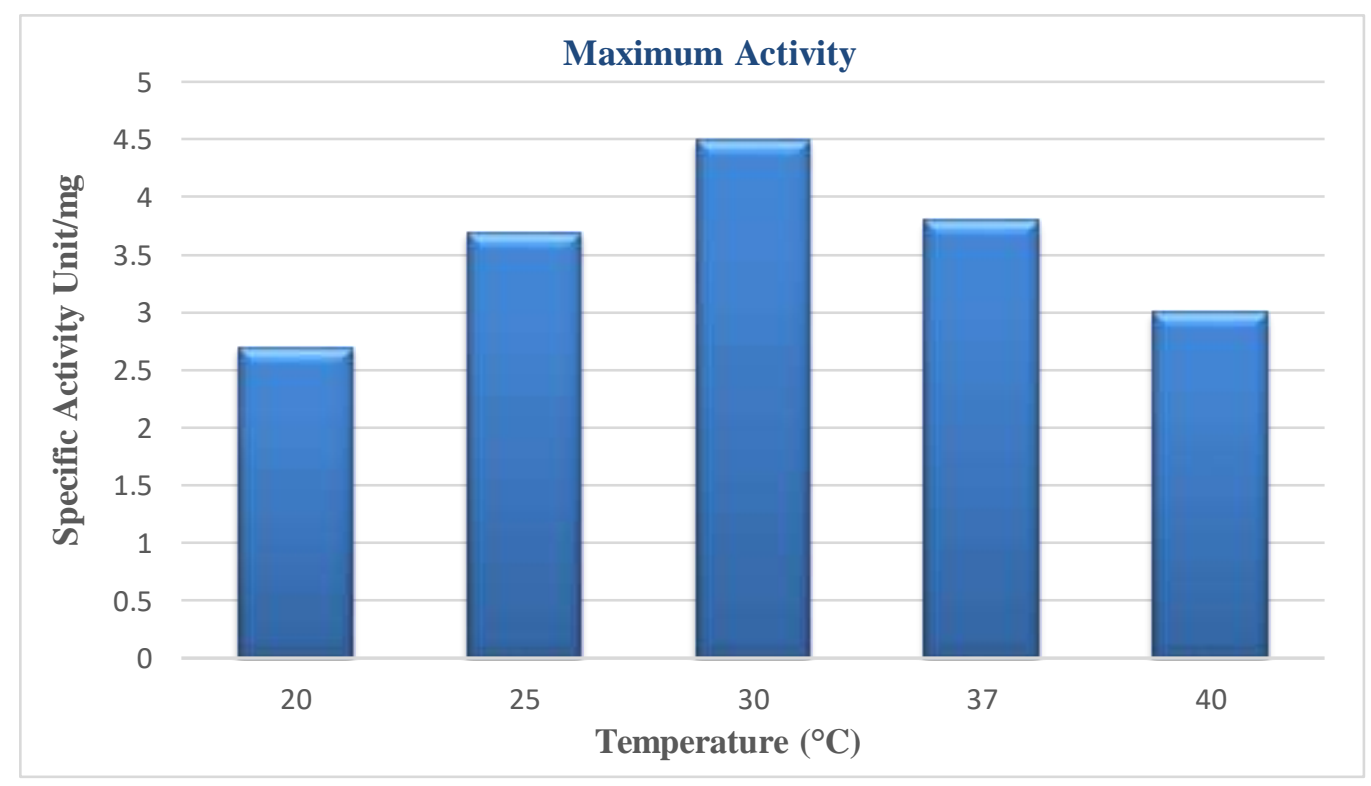

Figure 2. Effect of different ranges of temperatures $(20-40){ }^{\circ} \mathrm{C}$ on locally isolated L-glutamate oxidase production from Streptomyces bacteria. 


\subsection{Optimum pH for Enzyme Production}

In order to study the effect of $\mathrm{pH}$ on L- glutamate oxidase production, a production medium was prepared in diverse $\mathrm{pH}$ values consisting of (3.0,5.0, 7.0, 8.0, and 9.0). As in figure (3), the results showed the specific activity of L-glutamate oxidase enzyme synthesis by Streptomyces bacteria increased at $\mathrm{pH} 7.0$, reached 4.6 units per milligram protein while the lowest specific activity was 2.1 units per $\mathrm{mg} /$ protein at $\mathrm{pH} 3.0$ this indicates that the $\mathrm{pH} 7.0$ is the optimal $\mathrm{pH}$ for enzyme production [16]. This indicates that the bacteria grow well at this $\mathrm{pH}$ and are able to produce the enzyme. Based on these results, the $\mathrm{pH}$ of the production medium was adjusted to 7 in the later stages of the study.

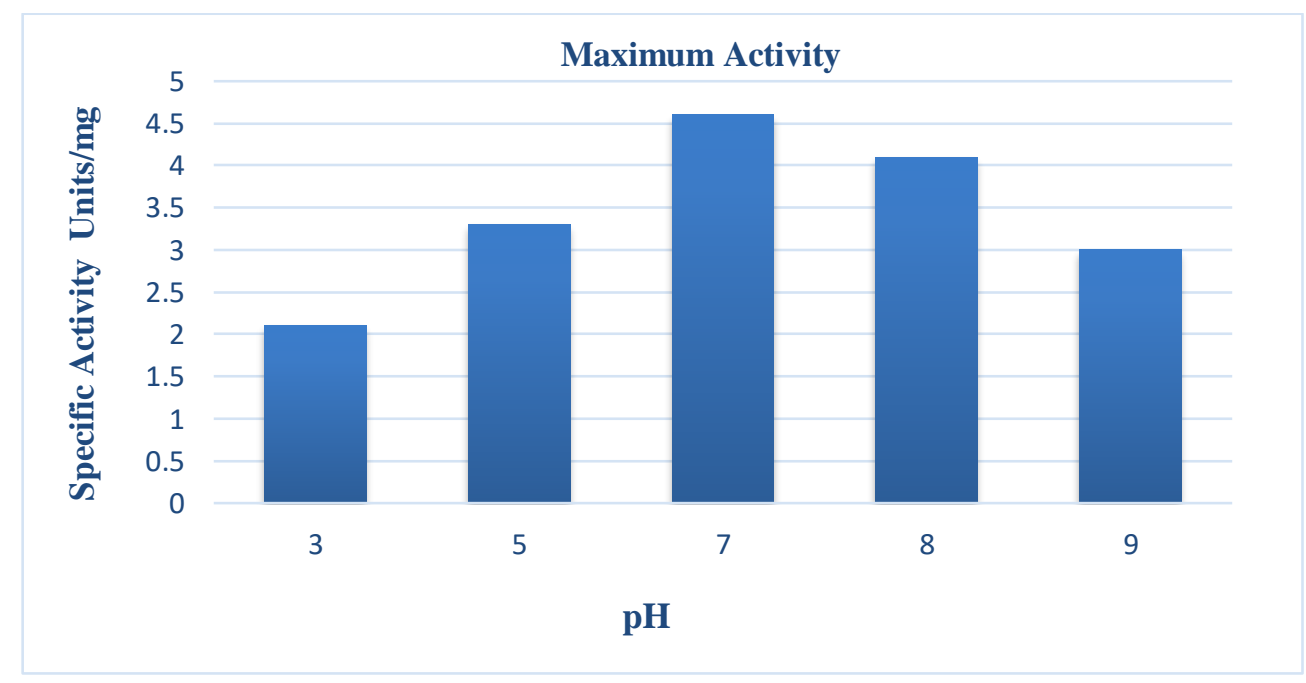

Figure 3. Effect of different range of $\mathrm{pH}$ values (3.0-9.0) on locally isolated L-glutamate oxidase production from Streptomyces bacteria.

\subsection{Determination of the effect of the enzyme on blood components}

Male and female blood samples were taken and treated with enzyme and hydrogen peroxide $\left(\mathrm{H}_{2} \mathrm{O}_{2}\right)$. The results in figures $(4,5,6)$ revealed that:

1) The enzyme's influence on blood components as indicated in the diagrams where it had been it's important to note that the enzyme had very little effect. Therefore, it can be concluded from these results that the enzyme is safe and can be applied and used in the future in various medical applications.

2) If the results obtained were compared according to the effect of the enzyme with the effect of hydrogen peroxide, the results showed that the hydrogen peroxide exhibited a simple decomposition in the blood components. Due to the facts, hydrogen peroxide causes toxicity in three main ways: corrosive damage, oxygen gas formation, and lipid peroxidation. So, concentrated hydrogen peroxide is considered hazardous, which can lead to local tissue damage. Ingestion of strong hydrogen peroxide ( $>35$ percent) can also result in the production of large amounts of oxygen. When the amount of oxygen released exceeds its maximum solubility in blood, a venous or arterial gas embolism might happen [17]. 


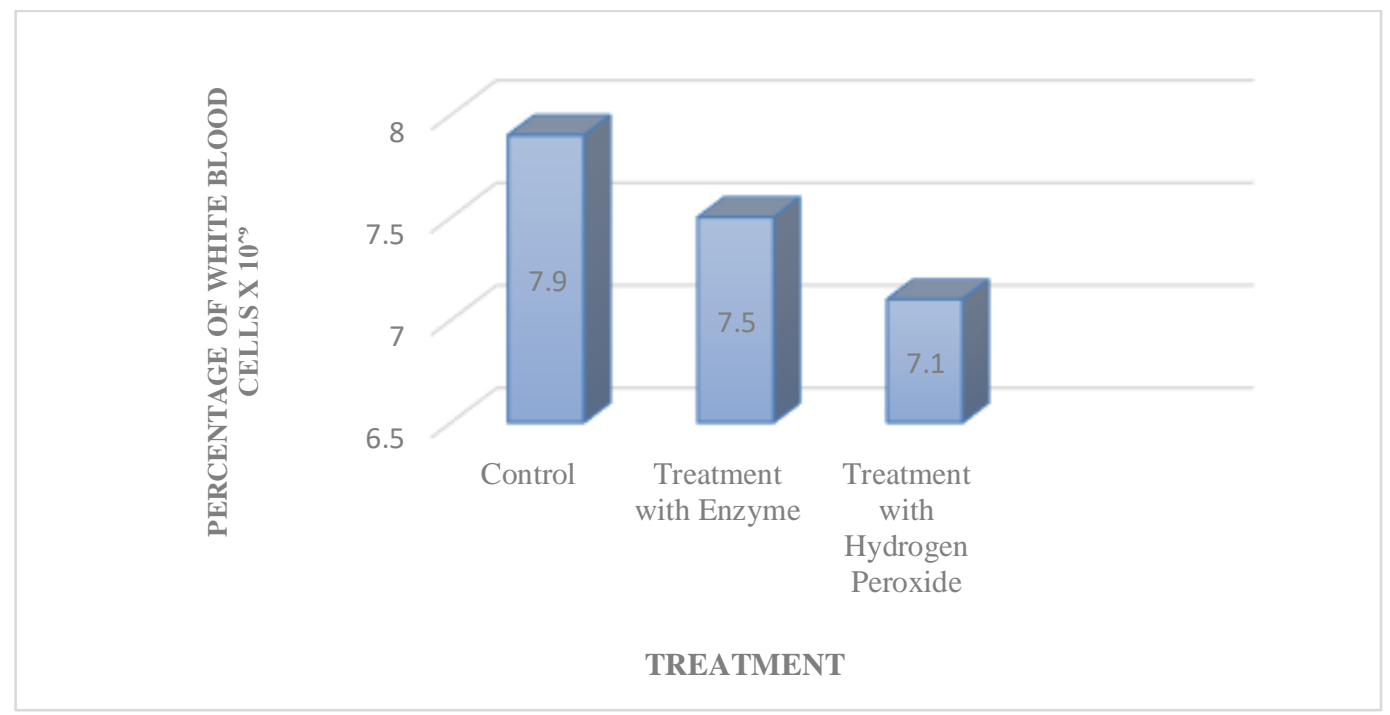

Figure 4. The effect of the studied treatments on the percentage of white blood cells.

Note* Studied treatment means

Control: Only human blood without any addition.

Treatment with enzyme means the human blood after adding 10 microliters of the enzyme to it. Treatment with hydrogen peroxide means the human blood after adding 10 microliters of hydrogen peroxide to it.

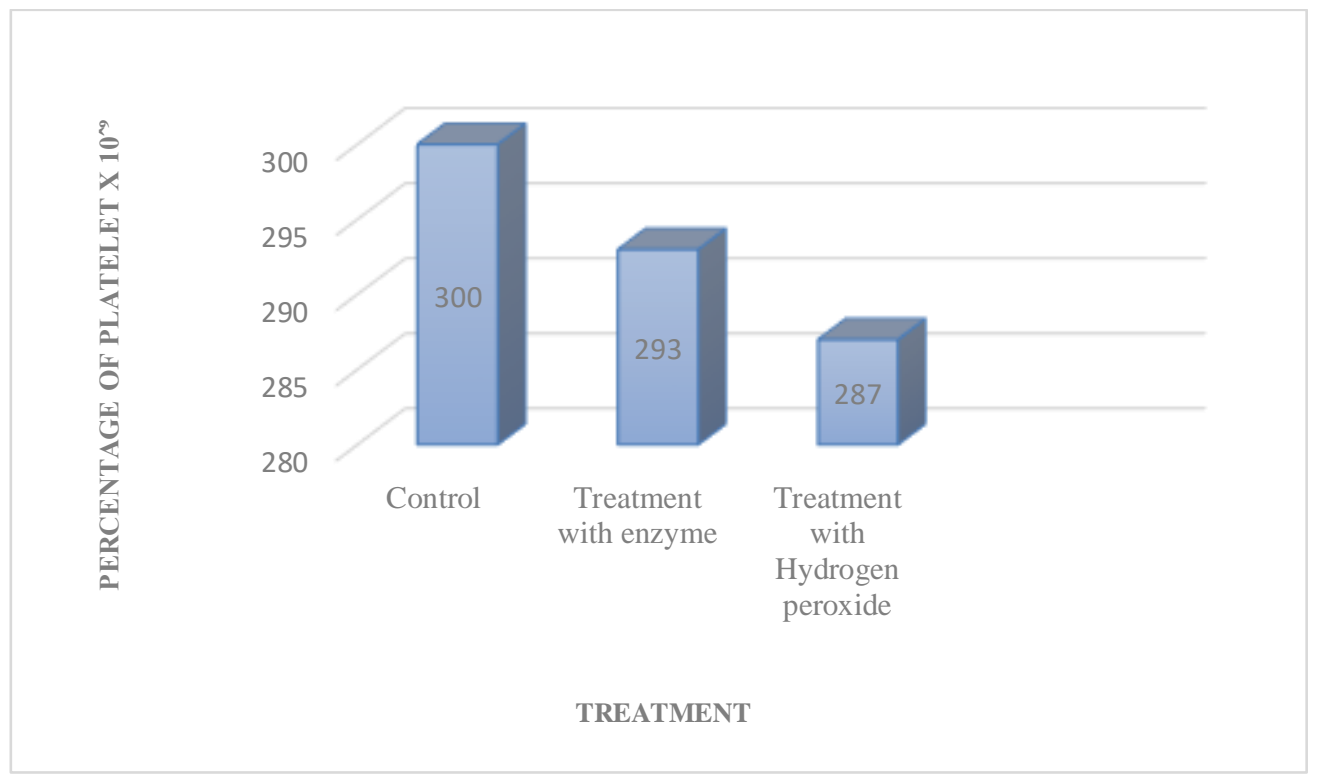

Figure 5. The effect of the studied treatments on the percentage of platelets. 


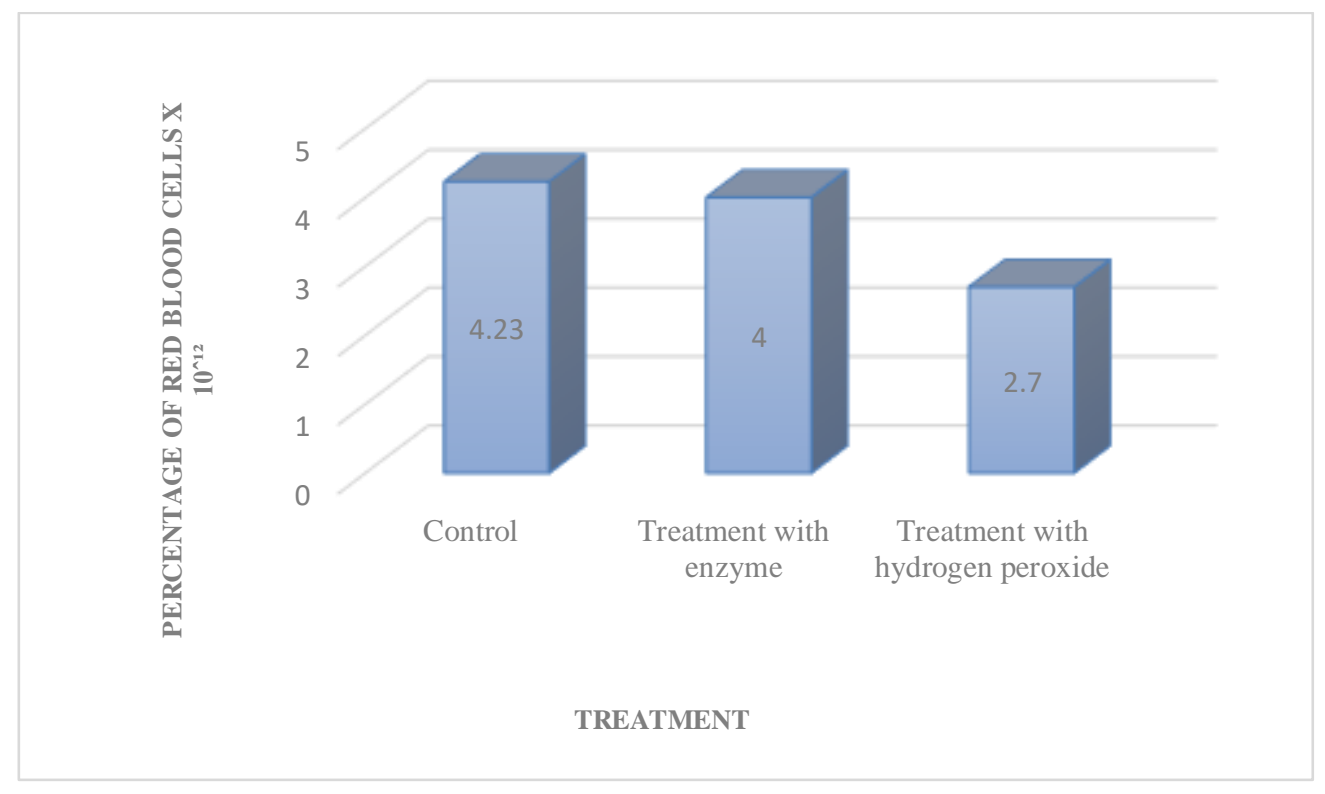

Figure 6. The effect of the studied treatments on the percentage of red blood cells.

\section{Conclusions}

The enzyme L- glutamate oxidase can be easily extracted after 60 hours of incubation of Streptomyces bacteria in a wheat bran medium. The effect of both temperature and $\mathrm{pH}$ on enzyme activity was studied to determine the favorable conditions for enzyme production. The results revealed that the best temperature and $\mathrm{pH}$ were at $30^{\circ} \mathrm{C}$, 7.0 respectively. So, because the enzyme has no effects when mixed with human blood. Studies on it might be developed in the future to use the enzyme in a wide range of medicinal applications. Future studies on the Lglutamate oxidase enzyme could also be expanded since it can also be used in various medical and analytical applications.

\section{Acknowledgment}

My deepest gratitude and thanks go to the Department of Applied Science Laboratories- University of Technology, Baghdad, Iraq for its help and facilities provided in some matters of the presented study. Sincere respect and deepest thanks go to the ministry of science and technology-environment and water research department laboratories for their help and continuous guidance throughout this work.

Conflict of Interest: The authors declare that they have no conflict of interest.

\section{References}

[1] S. Bhatia and S. Bhatia, "Introduction to enzymes and their applications," Introduction to Pharmaceutical Biotechnology; IOP Publishing Ltd.: Bristol, UK vol. 2, 2018.

[2] M. Vitolo, "Brief review on enzyme activity," World Journal of Pharmaceutical Research. Res., vol. 9, no. 2, pp. 60-76, 2020.

[3] J. M. DeMan, J. W. Finley, W. J. Hurst, and C. Y. Lee, Principles of food chemistry., Springer, 2018.

[4] M. Barakate, Y. Ouhdouch, K. H. Oufdou, and C. Beaulieu, "Characterization of rhizospheric soil streptomycetes from Moroccan habitats and their antimicrobial activities,". World Journal of Microbiology and Biotechnology., vol. 18, no. 1, pp. 49-54, 2002.

[5] G. A. Quinn, A. M. Banat, A. M. Abdelhameed, and I. M. Banat, "Streptomyces from traditional medicine: Sources of new innovations in antibiotic discovery," journal of Medical Microbiology., vol. 69, no. 8, p. 1040, 2020.

[6] K. F. Chater, "Recent advances in understanding Streptomyces," F1000Research, vol. 5, 2016. 
[7] F. Juttner and S. B. Watson, "Biochemical and ecological control of geosmin and 2-methylisoborneol in source waters,". Applied and environmental microbiology., vol. 73, no. 14, pp. 4395-4406, 2007.

[8] E. T. Quintana et al., "Streptomyces sudanensis sp. nov., a new pathogen isolated from patients with actinomycetoma," Antonie Van Leeuwenhoek, vol. 93, no. 3, pp. 305-313, 2008.

[9] J. Arima et al., "Recombinant expression, biochemical characterization and stabilization through proteolysis of an L-glutamate oxidase from Streptomyces sp. X-119-6," Journal of biochemistry., vol. 134, no. 6, pp. 805-812, 2003.

[10] N. Hussein and M. M. Khadum, "Evaluation of the Biosynthesized Silver Nanoparticles" Effects on Biofilm Formation," Journal of Applied Sciences and Nanotechnology., vol. 1, no. 1, pp. 23-31, Apr. 2021, doi: 10.53293/jasn.2021.11019.

[11] B. Jasim and E. Ali, "Enhanced Production of Fibrinolytic Enzyme from Pseudomonas aeruginosa by Optimization Media Components," Journal of Applied Sciences and Nanotechnology ., vol. 1, no. 2, pp. 5865, Jul. 2021.

[12] H. \& et al., "Determination The Optimum Conditions Of Laccase Production From Local Isolate Of Streptomyces Sp. Using Solid State Fermintation”, Iraqi Journal of Agricultural Sciences., vol. 49, no. 4, Sep. 2018.

[13] G. Lippi, C. Cattabiani, S. Bonomini, M. Bardi, S. Pipitone, and F. Aversa, "Preliminary evaluation of complete blood cell count on Mindray BC-6800," Clinical chemistry and laboratory medicine., vol. 51, no. 4, pp. e65-e67, 2013.

[14] S. O. Ike, T. Nubila, E. O. Ukaejiofo, I. N. Nubila, E. N. Shu, and I. Ezema, "Comparison of haematological parameters determined by the Sysmex KX-2IN automated haematology analyzer and the manual counts," BMC clinical pathology., vol. 10, no. 1, pp. 1-5, 2010.

[15] R.-Y. Wu and M.-H. Chen, "Identification of the Streptomyces strain KS3-5," Botanical Bulletin of Academia Sinica., vol. 36, 1995.

[16] S. Wachiratianchai, A. Bhumiratana, and S. Udomsopagit, "Isolation, purification, and characterization of L-glutamate oxidase from Streptomyces sp. 18G,” Electronic Journal of Biotechnology., vol. 7, no. 3, pp. 9-10, 2004.

[17] B. E. Watt, A. T. Proudfoot, and J. A. Vale, "Hydrogen peroxide poisoning," Toxicological reviews., vol. 23, no. 1, pp. 51-57, 2004. 